Kuchyn I., Skrypnyk R. $\bowtie$, Greben N., Lymar L.

Bogomolets National Medical University, Kyiv, Ukraine

\title{
Communicative Professional and Academic Competence of Medical Students Developed During their Ophthalmological Studies
}

Conflict of interest: nothing to declare.

Submitted: 28.11 .2021

Accepted: 14.02 .2022

Contacts: rimma.skrypnyk@gmail.com

\section{Abstract}

Purpose. To define the structure of the professional and academic communicative competence of the students exhibited during their ophthalmological classes and hold the study of the ophthalmological students' self-perception of the academic and communicative competence quality

Methods. A survey with the Bogomolets National Medical University students of the 4th study year was held in 2021. Fifty-six students were questioned, of which 36 (64.3\%) were females and 20 (35.7\%) males. The participation in questioning was voluntary. The respondents were asked to choose the main factor representing their professional communicative competence; the main factor representing their academic communicative competence; their strong side of communication with the patients; define the importance of the academic and professional communicative skills, and estimate their ability to communicate with the patient by the 5-point grade.

Results. The significance of well-shaped professional and academic communicative competence for the ophthalmological students is evident, with the students' choice of high significance of the communicative competence. The students' self-perception of their communicative and academic skills is rather high, though by their vision, their communicative professional and academic competence is represented mainly with their speaking skills and the ethical skills. Unfortunately, goal-setting, non-verbal skills and language skills of writing and reading are considered by the medical ophthalmological students as insignificant, though they play their role in the communicative competence structure. This evidences about the necessity of emphasizing these components during students' theoretical and practical courses by the teaching staff.

Keywords: communicative competence, ophthalmological students, doctor-patient communication 


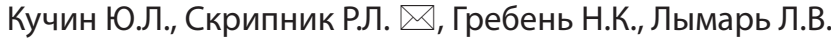

Национальный медицинский университет имени А.А. Богомольца, Киев, Украина

\title{
Коммуникативная профессиональная \\ и академическая компетентность студентов- медиков на занятиях по офтальмологии
}

\author{
Конфликт интересов: не заявлен \\ Подана: 20.11.2021 \\ Принята: 14.02 .2022 \\ Контакты: rimma.skrypnyk@gmail.com
}

Резюме

Цель. Определить структуру профессиональной и академической коммуникативной компетентности студентов на занятиях по офтальмологии; изучить особенности самооценки академической и коммуникативной компетентности студентами.

Материалы и методы. Были опрошены 56 студентов 4-го курса Национального медицинского университета имени А.А. Богомольца в 2021 г. Участие в опросе было добровольным. Респонденты должны были определить главный фактор, представляющий их профессиональную коммуникативную компетентность; фактор, представляющий их академическую коммуникативную компетентность; сильную сторону коммуникации с пациентами; определить степень важности академических и профессиональных коммуникативных навыков, а также оценить свою способность коммуницировать с пациентом по 5-балльной шкале.

Результаты. Анализ результатов опроса показал очевидную важность сформированной профессиональной и академической компетентности для студентов-офтальмологов с высокой степенью выбора значимости коммуникативной компетентности. Самооценка студентами их коммуникативных и академических навыков достаточно высокая, хотя согласно результатам опроса для большинства их коммуникативная профессиональная и академическая компетентность представлена навыками говорения и этическими навыками. К сожалению, постановка целей, невербальные навыки, навыки письма и чтения не принадлежат к значимым компонентам коммуникативной компетентности для студентов-офтальмологов, хотя они являются неотъемлемым компонентов в структуре коммуникативной и академической компетентности. Полученные данные свидетельствуют о необходимости углубленного изучения данных компонентов на протяжении обучения студентов-медиков.

Ключевые слова: коммуникативная компетентность, студенты-офтальмологи, коммуникация «доктор - пациент»

\section{- INTRODUCTION}

Traditionally, basic requirements to the medical students put forward by the higher medical educational institutions in Ukraine were represented with the requirements to their knowledge of theoretical and practical courses as well as the practical abilities and skills of their application on practice. This was necessary for examining the patient, 
establishing diagnosis and prescribing the treatment. Unfortunately, until recently, the issue of medical communicative competence has been neglected in Ukrainian medial education. The physicians' professional competence notion dates back to G. Derbyshire's 1965 article where he raised a very significant ethical and deontological question of physician's competence [1], the same question renewed its importance in 1998 by D. McClelland studies of competence and intellect [2]. The physician's competences, including the communicative, were studied by Guerrero D (who studied the competence overall) [3], Dunn W.R. (who defined basic physicians' competences) [4], and Koenig T.W. (who studied medical students' competences) [5]. The Ukrainian studies of medical communicative competence appeared less than 10 years ago, represented by such researchers as M. Mruga [6]. and N. Stuchynska [7], not to mention those dedicated to academic communicative competence, of which the authors found no evidence in Ukrainian pedagogical authors and the University curricula. In Ukraine by 2021 the issue of academic communicative competence has not been studied at all.

The professional and academic communicative competence plays a significant role in the activity of each specialization doctor, particularly the ophthalmologists. The importance of vision for the patients, their fear of losing eyesight and feeling shame for bad sight as the sign of ageing need for well-shaped communicative skills of the ophthalmologists. So, the authors decided to study the characteristic of professional and academic communicative competence in the ophthalmological students during their practice, as this could show all predispositions for the positive or negative development of the trait.

\section{- PURPOSE}

As the notion of the professional and academic communicative competence of physicians has been insufficiently studied in Ukraine, to define the structure of the professional and academic competence of the students exhibited during their practical (ophthalmological) classes and to hold the study of the ophthalmological students' selfperception of the competence quality.

\section{- THEORETICAL AND PRACTICAL STUDY BACKGROUND}

Basing on the authors' personal experience of communication in the educational, academic and medical professional environment, the following definition of the studied competence has been proposed: the professional and academic communicative competence is a combination of knowledge and skills of productive professional and academic communication, acquired through theoretical studied and practical experience, which are applied during such interaction with the most beneficial results.

The author's model of the professional and academic communicative competence by L. Lymar defines the following components: cognitive competence (represented with the knowledge on the communicative structures, methods of questioning the ophthalmological patient, ways of interaction with medical patients, etc.), practical (skills which developed after practice training or acquired after experience of the ophthalmological practice) and the individual one (representing peculiarities of the ophthalmologist's communicative mindset, goals of his professional interaction with the patient, etc.). When mentioning the professional communicative competence, the authors mean knowledge, abilities and skills of effective communication with the patients, while 
the academic communicative competence represents with the knowledge, abilities and skills of effective communication in the academic environment: with tutors, students and other participants of the academic process. The professional communicative competence is traditionally considered as one of the irreplaceable components of the physician's activity, while the academic communicative competence is essential for both students and scientists. Herein the professional communicative competence is regarded.

The cognitive component is developed through studying theoretical subjects underlying the ophthalmological examination (normal and pathological anatomy, normal and pathological physiology, histology and all terms and notions referring to Ophthalmology; Doctor-Patient Communication course, etc.). Practical component is developed during students' practice, when the students are offered a standard sequence of patient questioning and examination in case of ophthalmological complaints. This includes medical phrases regarding general examination (requirements to take a certain body position, turn the body part, etc.) and the ophthalmological examination and questioning (questions regarding the vision, problems with the eyes or vision, vision acuity, certain disturbances related to the vision). The issue of questioning an ophthalmological patient with regard to his deteriorating vision should be very individual, especially if the outcome of the treatment may result in the so-called "negative news", when the SPIKES protocol should be used. Thus, the physician should avoid phrases which will emphasize the patient's possible (future) disability, like "your vision is deteriorating", "your vision is going to deteriorate more", "there is a possibility of losing vision", etc. While dealing with the elderly, in whom the vision loss may be related to the senile changes, ophthalmologist should be particularly careful, not to induce iatrogenic stress and anxiety. Apart from the general questions, regarding the vision itself and any sensations related to the eye, the ophthalmological students should learn how to ask about family history of eye diseases (Could you remember eye problems in any of your relatives?), taking medications which may affect the vision (Could you recall the drugs which you have taken recently?), personal history of eye disease (Is this your first ophthalmological visit?) and the occupation which may be harmful for the eye's health (Could you tell about your profession?). No direct hints on the danger of the occupation or any family history should be made in the beginning (like, "you may have the same disease that your mother had, we will check it").

As for the ophthalmological examination itself, the students should learn how and in what order to question the patients on: the vision problems (using the impersonal constructions, like "What seems to be the matter or what seems to trouble you?), the corrective methods that the patient has already used (Have you used lenses or glasses?), or, if it is evident (How long have you been using the lenses/glasses and could you tell me about it in details?).

The vision acuity test, being the most essential for establishing the ophthalmological diagnosis, needs for certain indication of the doctor-patient communication: so, before performing the test it is important for the ophthalmologist to explain to the patient what procedure he is going to undergo, emphasizing it will be painless. The patient's ability to identify the symbols from a distance shouldn't be commented at once by the physician. After both the visual acuity test and the refraction test, the ophthalmologist should inform the patient on his condition, trying to be impersonal. If any other procedures are required, this should be stated without any hazardous messages (I'm afraid, there is a problem, we need some more tests). No negative statements should be made when 
communicating with the patient. In the communication with ophthalmological patients, like any other, personal opinions shouldn't be expressed, but only the evidence-based information ("according to the last researches, or the last publications show that"). All the recalled skills are represented not only with the correct knowledge of language and medical terms, but with respectful attitude to the patient, observance of ethical doctorpatient communication standards, correct use of non-verbal signs, etc. Though, most part of the communicative and academic competence here refers to the knowledge of correct phrases to be used and their appropriate use.

The authors consider that high level of the professional communicative competence should be stated when ophthalmological student shows deep knowledge of the medical terms and uses them correctly in communication, being able to explain comprehensively information to the patients, the student is successful in his communication with the patient (the goals-questioning, explaining the procedure or treatment, etc., are reached, without any reprimands from the patient's side), with both verbal and non-verbal characteristics of the communication defined as good. The assessment of high professional competence of the ophthalmological students is made by the teachers, including teachers' personal opinion, the patient's opinion and the general effectiveness of the student (absence of conflict-provoking situations, complaints, well-performed tasks). Average level of the professional communicative competence can be stated when the student shows sufficient knowledge of the medical terms and procedures, thus, being able to communicate with the patients, though some mistakes in communication can be stated by the teacher or are evident from either incomplete information or further patient's referrals (incorrectly explained procedure, scared patients, complaining patients, providing negative information without following the accepted sequence). Poor communicative competence level of ophthalmological students can be stated when the student is unable to deliver his communicative message to the patients, due to his own poor knowledge of the medical issue, procedures, ethical bases, etc. The patients in such case are confused, scared or angry, quite usually complaining. The authors' personal experience of teaching medical students (particularly ophthalmological, on their $5^{\text {th }}$ year of medical studied) doesn't include any medical students with poor communicative competence.

To add, apart from the communicative professional competence, medical students should also master the academic competence skills, representing their knowledge and skills of interaction at the ophthalmological classes with themselves, tutor and the patients, being an inseparable component of their academic process. The academic communicative competence includes the thorough knowledge of the academic language and the skills of its appropriate use as well as the knowledge and skills of other factors, such as: nonverbal communication characteristics, ability to set goals and reach them in the academic environment, personal readiness of the participant for the communication in academic environment. According to the authors' experience, medical students pay attention to the language component (academic expressions, correct use of terms, etc.), but sometimes neglect the essential ethical and behavioural rules of the academic interaction (being late, neglecting the dress code, revealing confidential information about patients during practice to other students, sometimes showing signs of malpractice or gross negligence).

Both communicative professional and academic competences of medical students are equally important, being studied by the medical students within the courses of Ukrainian and English languages (with professional communication component), courses of 
Philosophy, Deontology, Psychology of Doctor-Patient Communication, as well as during each practice course.

\section{- MATERIALS AND METHODS}

In order to find out about the ophthalmological student's attitude and self-assessment of the academic communicative and professional communicative competence, a survey with the Bogomolets National medical university students of the 4th study year was held in 2021. Fifty-six students were questioned, of which $36(64.3 \%)$ were females and $20(35.7 \%)$ - males. The participation in questioning was voluntary. The respondents were asked to choose the main factor representing their professional communicative competence from the knowledge and skills of speaking; knowledge and skills of reading; knowledge and skills of writing; nonverbal issues; knowledge and skills of ethical principles; skills of goal-setting. Then the respondents were asked to choose the main factor representing their academic communicative competence out of: knowledge and skills of speaking in academic environment; knowledge and skills of reading in academic environment; knowledge and skills of writing in academic environment; knowledge and skills of ethical behaviour principles in academic environment; non-verbal skills; skills of goal-setting and reaching them. Also, the respondents were asked to choose their strong side of communication with the patients: dialogue, explanation, questioning, written communication, or their choice; and the weak side from: dialogue, explanation, questioning, written communication, or their choice. Regarding the importance of the academic and professional communicative skills, the respondents should have chosen from the options: important, more important than unimportant, more non-important than important and not important, with the extra choice: can't decide. Finally, the questioned students were asked to estimate their ability to communicate with the patient by the 5 -point grade, with 5 being maximum ability, and 1 being total inability to communicate.

\section{- RESULTS}

The following data were obtained: as for defining the medical communicative competence main factor, 25 people (44.6\%) chose knowledge and skills of speaking, 20 (35.7\%) - knowledge and skills of applying ethical principles; 8 (14.2\%) - non-verbal knowledge and skills, 4 (7.14\%) - skills of goal-setting, 1 (1.78\%) - knowledge and skills of writing. The ability of reading was considered insignificant as only one respondent chose it.

As for the academic communicative competence main factors, 28 respondents $(67.9 \%)$ chose knowledge and skills of speaking, 21 (37.5\%) - knowledge and skills of ethical interaction, $11(19.64 \%)$ - knowledge and skills of writing, 12 (21.4\%) - skills of goalsetting, 8 (14.2) - non-verbal skills and 4 (7.14\%) - knowledge and skills of reading.

As for choosing one's strong side in communication with the patients, 28 (50\%) chose explanation, and $23(41.1 \%)$ - dialogue, the other options were almost not chosen. Weak side was as defined as written communication by 37 people (66.1\%), and ability for dialogue by $10(17.9 \%)$ with other options such as questioning, explaining or empathy chosen by single respondents.

Assessing the importance of the skills of communication, 54 (96.4\%) the respondents stated their importance, and 2 (3.6\%) stated they were more important than unimportant. The self-assessment of the ability to communicate in the environment by the ophthalmological students showed quite high self-estimation of their communicative 
skills, as $18(32.1 \%)$ respondents stated they has excellent communicative skills, corresponding to grade $5 ; 32(57.1 \%)$ - good, and only $6(10.7 \%)$ stated about satisfactory communicative professional and academic skills, corresponding to the grade 3 .

\section{- DISCUSSION}

The significance of well-shaped professional and academic communicative competence for the medical (ophthalmological students) is evident, which is understood by the students themselves, who totally chose high significance of the communicative competence (as the options of low importance were not chosen at all). The students' selfperception of their communicative and academic skills is rather high, when only $10.7 \%$ noted low level of the skills, and no one claimed about unsatisfactory level. Such high selfassessment may be related to slightly incorrect skills of self-estimation, as in the beginning of the survey, choosing from the most important factors of the professional communicative competence the students chose speaking knowledge and skills: $44.6 \%$ chose knowledge and skills of speaking and $35.7 \%$, while within the academic communicative competence components $67.9 \%$ chose knowledge and skills of speaking, and $37.5 \%$. So, for the ophthalmological students, their communicative professional and academic competence is represented mainly with their speaking abilities and skills (which are grounded on the language knowledge, knowledge of medicine, theory of examination and diagnosis) and the ethical skills (which rely on the deontological knowledge). According to our model of the professional and academic communicative competence, combination of its three components (cognitive and practical, represented with knowledge and skills of communication, with the individual one (showing how successfully a person implements them due to personal characteristics) predisposes for the effective communicative competence level. Here, gaps in writing or reading cognitive-practical component will decrease the total level of the competence.

Low choice of significance of writing $(1.78 \%$ chose it as a most significant factor for professional communicative competence) and reading ( $7.14 \%$ chose it as an important academic competence factor, and none - as the communicative one) show the distorted picture of communication observed by the students, as the communication is much wider than only speaking. Speaking represents the final part of communication, but the gaps in reading, writing and listening as well as poor ability of an ophthalmologist to set goals before communication or poor knowledge of non-verbal component of communication will lead to low effectiveness. This is confirmed by another survey, where the respondents stated their strong communication strategy was explanation (50\%), which needs low level of another participant co-involvement. It is interesting to note that the $66.1 \%$ defined their weak side of communicative skills as written communication, which means it is considered as a component of communication by the respondents, but neglected in the other survey answers. All this shows that the goal-setting, non-verbal skills and language skills of writing and reading are considered by the medical ophthalmological students as insignificant, though they play their role in the communicative competence structure. This evidences about the necessity of emphasizing these components during students' theoretical and practical courses by the teaching staff. 


\section{- CONCLUSIONS}

The professional and academic communicative competence of medical students is a combination of knowledge and skills of productive professional and academic communication, acquired through medical studies, applied during such interaction with the most beneficial results. The model of the professional and academic communicative competence regarding ophthalmological students includes cognitive competence, practical and the individual one. In order to define the importance of the competence components and their self-assessment by the ophthalmological students, a survey with the O. Bogomolets National medical university students of the 4th study year was held in 2021. The significance of well-shaped professional and academic communicative competence for the ophthalmological students was evident, as the respondents chose high significance of the communicative competence. The students' self-perception of their communicative and academic skills is rather high, though by their vision, their communicative professional and academic competence is represented mainly with their speaking abilities and skills and the ethical skills. Goal-setting, non-verbal skills and language skills of writing and reading are considered by the medical ophthalmological students as insignificant, which evidences about the necessity of emphasizing these components during medical studies.

\section{REFERENCES}

Derbyshire R.C. (1965) What should the profession do about the incompetent physician? JAMA, 1965, vol. 194, no 12, pp. 1287-1290.

McClelland D.C. (1998) Testing for competence rather than for "intelligence. American Psychologist, 28 (1), pp. 1-14.

3. Guerrero D., De los Ríos I. (2012) Professional competences: a classification of international models. Procedia-Social and Behavioural Science Journal, vol. 46, pp. 1290-1296.

4. Dunn W.R., Hamilton D.D., Harden R.M. (1985) Techniques of identifying competencies needed of doctors. Medical Teacher, vol. 7, no 1, pp. $15-25$.

5. Koenig T.W. et al. (2013) Core personal competencies important to entering students' success in medical school: what are they and how could they be assessed early in the admission process? Academic Medicine, vol. 88, no 5, pp. 603-613.

6. Mryga M.R. (2017) Structural-functional model of professional competence of a physician as a basis for diagnosing his primary qualities. (PhD Thesis). Kyiv, 27p. (In Ukrainian)

7. Gruzieva T.S., Stuchynska N.V., Inshakova H.V. (2020) Research on the effectiveness of teaching biostatistics of future physicians. Wiadomosci lekarskie (Warsaw, Poland: 1960), 73(10), pp. 2227-2232. 